\title{
Improving Perceptions of the Marine Environment by Hands-on Environmental Education: The Case of Hannan City, Osaka, Japan
}

\author{
Kana Kuroda ${ }^{1 *}$
}

${ }^{1}$ Osaka Prefecture University, Graduate School of Humanities and Sustainable System Sciences, JAPAN
*Corresponding Author: kuroda_k@marine.osakafu-u.ac.jp

Citation: Kuroda, K. (2021). Improving Perceptions of the Marine Environment by Hands-on Environmental Education: The Case of Hannan City, Osaka, Japan. European Journal of Sustainable Development Research, 5(2), em0156. https://doi.org/10.21601/ejosdr/10843

\section{ARTICLE INFO}

Received: 23 Nov. 2020

Accepted: 13 Feb. 2021

\begin{abstract}
Coastal and marine environments provide ecosystem services related to human well-being. However, the link between these ecosystem services and lifestyle of nearby populations is rarely recognized. This study proposes environmental events involving a series of hands-on activities, stimulating families' awareness of both the local foods (rice, fish, and seaweed) and marine environment and linking them to the coastal environment. The present study quantitatively evaluated the changes in adults' perceptions of Osaka Bay and attitudes on rice and fish consumption through a year-long program. We found that continuous participation (increased visit to the coastal area) effectively changed the participants' perceptions of Osaka Bay and increased opportunities for eating local foods at home. In addition, the living experiences and realistic experiences increased the participants' familiarity with Osaka Bay. These results suggest that the proposed program is a powerful tool that can assist marine and conservation education outside school.
\end{abstract}

Keywords: environmental education, coastal environment, perception change, attitude change

\section{INTRODUCTION}

Coastal and marine environments provide various ecosystem services to humans, such as climate regulation, nutrient cycling, food production, and recreation opportunities related to human well-being. The link between these ecosystem services and the lifestyle of nearby populations is rarely recognized. Coastal and marine environments have been burdened by anthropogenic pressure resulting in threats, such as coastal eutrophication, marine pollution, destruction of habitat, overfishing, and discarded plastics. The degradation of the marine environment can be partially attributed to the collective impact of people's daily behavioral and lifestyle choices (McKinley and Fletcher, 2010). The recent framing of conservation shifted from "Nature for people" to "People and nature," which emphasizes the importance of cultural structures and institutions in developing sustainable and resilient interactions between human societies and the natural environment (Mace, 2014). Thus, it is important to increase people's awareness of the ecosystem services provided by coastal and marine environment.

In the final report of the UN Decade of Education for Sustainable Development (UNESCO, 2014), adult learning and education is recognized as an appropriate means to achieve sustainable development. Adult participation in solving environmental problems is essential and informal environmental education is a key to securing it (Sutherland and Ham, 1992). According to Torres et al. (2019), litter reduction programs should first engage adults, such as educators, facility staff, parents, and student leaders, because adult role models will further integrate pro-community and pro-environmental messages and actions. Moreover, adults influence the eating behavior of children (Pearson et al., 2009). Thus, it is important to examine the effect of informal environmental education in developing the awareness, perceptions, and attitudes of adults.

Environmental education could inspire interest in marine environment. Recent research related to lifestyle and marine environment includes marine litters (Torres et al., 2019), aquatic invasive species (Sharp et al., 2017), water quality (Pendleton et al., 2001), and leisure boats (Wester and Eklund, 2011). From the perspective of seafood related lifestyle, Seafood Watch program navigate people choose the sustainable seafood by providing global information of fish species based on the scientific data (Monterey Bay Aquarium, 2020). In contrast, there are few topics in nutrient cycling between land and sea, which is one of the ecosystem services of the marine ecosystem.

A number of studies have examined people's awareness, perceptions, and attitudes toward the marine environment and its conservation (Forrester et al., 2017; Hein et al., 2019; 
Hynes et al., 2014; Leisher et al., 2012; Pendleton et al., 2001; Sattler and Bogner, 2017). Hein et al. (2019) surveyed the benefits and limitations of coral restoration projects from the perspectives of stakeholders noting the link between the broad nature of potential socio-cultural benefit to coastal restoration efforts. Among several reported benefits, "Education" was linked to the awareness of coral reefs with their associated threats and solutions, and "community involvement" was described as a hands-on experience practically involving people in outdoor and practical activities, thereby significantly influencing their awareness and perceptions toward marine environment. Otto and Pensini (2017) concluded that the frequency of nature-based environmental education impacts the ecological behavior via environmental knowledge and connectivity to nature. Similar conclusions on the positive influence of the frequency of visits on both perceptions of urban green spaces and willing to pay for its conservation were obtained by Tian et al. (2020). The conclusions of Otto and Pensini (2017), and Tian et al. (2020) were based on the past experiences of respondents only. In this regard, it is imperative to identify the activities that could change people's perceptions and behaviors toward the marine environment and their food-related lifestyle.

The study site of the marine environment of Osaka Bay, an enclosed sea area in central Japan, has been degraded by problems, such as red, blue, and green tides, especially after the rapid economic growth in the 1960s and 1970s. Heavy metal industries and transportation ports have replaced beaches, mudflats, and seagrass at Osaka Bay with landfill sites, preventing the easy access for Osaka residents. Accordingly, there are negative public perceptions toward Osaka Bay as most of the residents are unfamiliar and unconcerned with both the bay and its local fish (Osaka Prefecture, 2014; Kuroda and Otsuka, 2018). Published literature has attempted to promote awareness of specific issues related to marine environment and conservation (Forrester et al., 2017; Hein et al., 2019; Sattler and Bonger, 2017; Sharp et al., 2017; Torres et al., 2019); however, there are only few reports on people's perceptions about the sea itself.

Because most of the residents in Osaka are unfamiliar with both the bay and its local fish, we emphasized the importance of improving people's perceptions toward Osaka Bay as the first step for its conservation. The present study proposed hands-on environmental events with specific focus on both land and marine environment and quantitatively evaluated the changes in the adults' perceptions toward Osaka Bay, and their attitudes toward their rice and fish consumption. The terms "perceptions" and "attitudes" were used for evaluating Osaka Bay and consumption of rice and fish, respectively. This study followed two research questions: (1) Does a continuous participation provide positive influences on the participants' perceptions and food-related attitudes? (2) How residence, gender, and age influence the change of perceptions and attitudes?

\section{MATERIAL AND METHODS}

\author{
Field sites: Osaka Bay and Hannan City, Osaka
}

Osaka Bay is an enclosed sea area in central Japan surrounded by a large population (about 8.8 million people in 2021). Fish and rice yield in Osaka Prefecture in 2017 are $18,737 \mathrm{t}$ and 26,100 t, respectively (MAFF, 2017). Fishery methods in Osaka Bay are as follows: bottom trawls for flounder, gillnet fishing for Spanish mackerel, purse seine fishing for anchovy and sardine, pots and traps for octopus and shrimp, and aquaculture for nori (Japanese term for the edible seaweed Pyropia yezoensis) and wakame (Japanese term for the brown edible seaweed). Main fish species in Osaka Prefecture are anchovy and sardine, which consists of about $80 \%$ of total fish yield in 2017. From the perspectives of fish yield, Osaka Bay cannot afford adequate amount of fish to all the residents in Osaka Prefecture. Therefore, excessive consumption can threaten the sustainability of local fish supply. However, people's unfamiliar with local fish can cause unawareness of marine ecosystem; thus, proposed events focused on improvement of people's perceptions and attitudes.

Production yield of seaweed (nori and wakame) in 2017 is 288 t in Hannan City. Hannan City is located southwest of Osaka Prefecture facing Osaka Bay to its north and the Izumi Mountains to its south (Figure 1). Hannan City was dominated by the fishery and agriculture industry until the 1940s when it became a city commuter town through urbanization. Some residents enjoy fishing, swimming, and rigging clams at the beach, however, such activities are available only southern Osaka Bay because most of the coastal area became landfill sites.

\section{Event Description}

In this study, a year-long marine-related environmental program for adults and young children was conducted in Hannan City. Hannan City has easier access to the coast via a seminatural beach; thus, it was recognized as a suitable area for learning about the local marine environment. The program involved a series of hands-on activities called "Let's taste the link between the land and sea," stimulating families' awareness of both the local foods (rice, fish, and seaweed) and marine environment, and linking them to the coastal environment. Originally designed and organized by a nonprofit organization, the program exposed the participants to continuous on-site experiences relating to rice, fish, and nori. Nori sheets are commonly used to prepare sushi, a traditional Japanese dish. It is grown by photosynthesis through the consumption of nutrients mainly flown from land. These foods are extremely popular in Japan and represent local foods supplied by the nutrient cycle between land and sea, which is one of the ecosystem services of the marine ecosystem. Therefore, this program attempted to inform participants about these ecosystem services through hands-on events in a local framework.

The program consisted of six events throughout the year (Table 1): planting rice in June, watching marine creatures and undertaking fishery experiences in August, rice harvesting in September, preparing nori harvesting in January, nori harvesting and making nori sheets in February, and making 


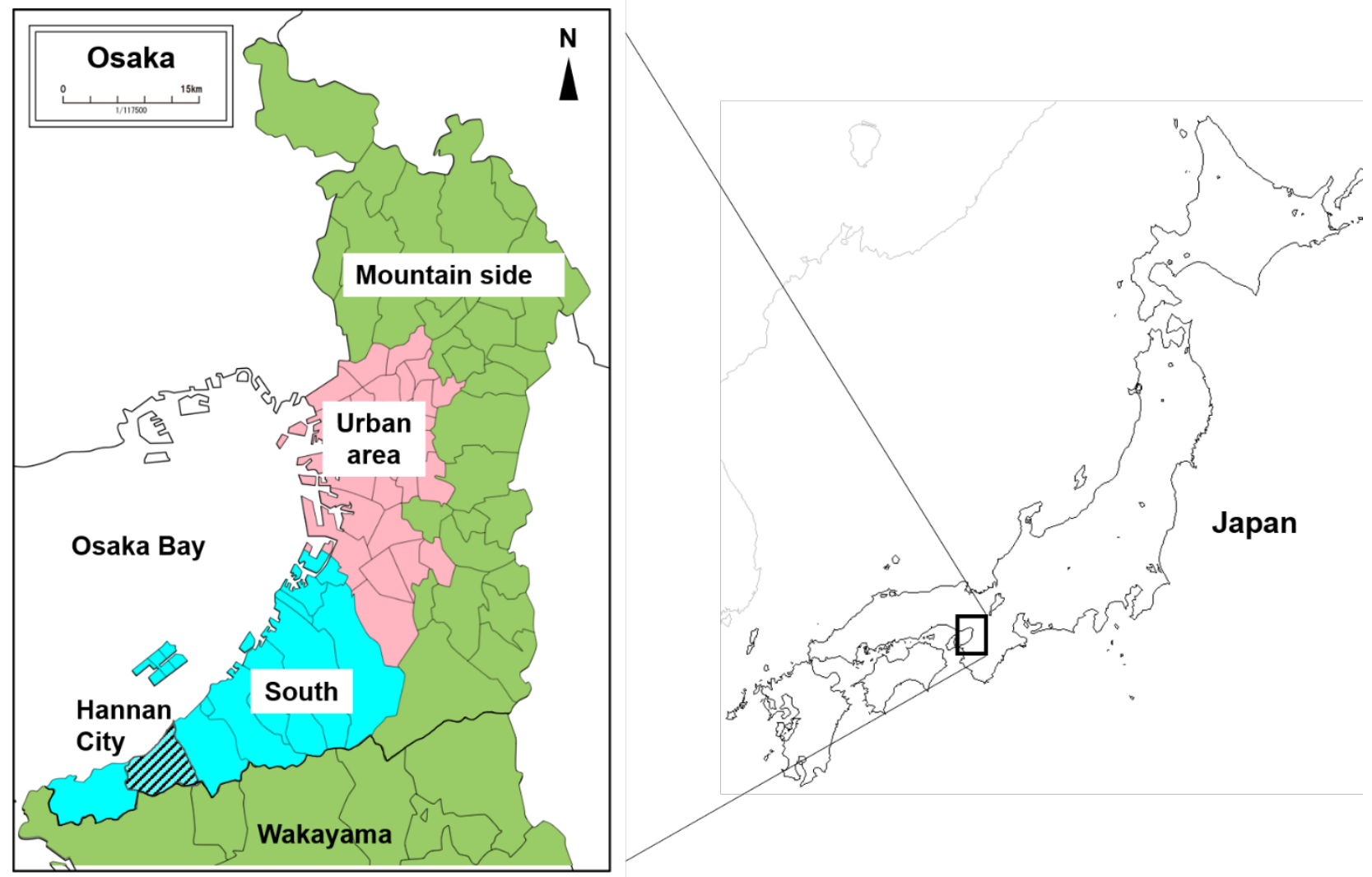

Figure 1. Location of the field sites: Osaka Bay and Hannan City

Table 1. Descriptions of hands-on environmental events

\begin{tabular}{|c|c|c|c|c|c|c|}
\hline Time line & June & August & September & January & February & March \\
\hline$(\mathrm{min})$ & Event 1 & Event 2 & Event 3 & Event 4 & Event 5 & Event 6 \\
\hline 15 & \multicolumn{6}{|c|}{$\begin{array}{l}\text { In the beginning, event organizer explained how our life is linked with the ecosystem service of the coastal area related to the } \\
\text { nutrient cycle between land and sea. }\end{array}$} \\
\hline 30 & \multicolumn{5}{|c|}{ Fishermen and the event staff demonstrated the content of the event. } & \multirow{2}{*}{$\begin{array}{c}\text { The event organizer } \\
\text { summarized the six } \\
\text { events using slides } \\
\text { and pictures. }\end{array}$} \\
\hline 45 & \multirow{4}{*}{ Plant rice. } & $\begin{array}{l}\text { Fishery experience } \\
\text { (beach seining) }\end{array}$ & \multirow{4}{*}{ Harvest rice } & \multirow{5}{*}{$\begin{array}{l}\text { Make the tool for } \\
\text { making nori sheet }\end{array}$} & \multirow[t]{3}{*}{ Harvest raw nori. } & \\
\hline 60 & & Watch creatures & & & & \multirow{3}{*}{ Make rice ball. } \\
\hline 75 & & caught in beach & & & & \\
\hline 90 & & seining. & & & Make original nori & \\
\hline 105 & \multirow[b]{2}{*}{ Clean up } & \multirow[b]{2}{*}{$\begin{array}{l}\text { Fishery experience } \\
\text { (catching octopus) }\end{array}$} & & & sheet using the tool & \multirow{3}{*}{$\begin{array}{l}\text { Lunch (rice ball with } \\
\text { Japanese soup } \\
\text { including local } \\
\text { seafood) }\end{array}$} \\
\hline 120 & & & Clean up & Clean up & $\begin{array}{l}\text { participants made in } \\
\text { event } 4\end{array}$ & \\
\hline 135 & $\begin{array}{c}\text { On-site } \\
\text { questionnaire survey }\end{array}$ & \multirow{2}{*}{ Clean up } & $\begin{array}{c}\text { On-site } \\
\text { questionnaire st }\end{array}$ & $\begin{array}{l}\text { On-site } \\
\text { stionnaire survey }\end{array}$ & Clean up & \\
\hline 150 & & & & & $\begin{array}{c}\text { On-site } \\
\text { questionnaire sur }\end{array}$ & Clean up \\
\hline 165 & & $\begin{array}{c}\text { On-site } \\
\text { questionnaire surv }\end{array}$ & & & & $\begin{array}{c}\text { On-site } \\
\text { questionnaire survey }\end{array}$ \\
\hline
\end{tabular}

and consuming rice balls from the self-prepared rice and nori in March (Figure 2). The local fishermen provided the rice field and raw nori. In August, the participants directly touched local fish and learned about their seasonality and traditional fishing methods from local fishermen. In addition, participants brought home the local fish they caught. In September, the participants can buy new rice which is harvested by fishermen before the event. In February, participants brought home raw nori provided by local fishermen, who demonstrated how to cook them at home. In the last event, the event organizer summarized all the events using slides and pictures and narrated the environmental link between our life and the ecosystem service of the coastal area. All the events except event 6 started at 1:00 p.m. and event 6 started at 11:00 a.m. because the event 6 includes lunch time. All the events took almost 3 hours. As shown in Table 1, the program promoted eating local foods at home. Some schools in Japan incorporate rice planting and harvesting outside their curriculum. 

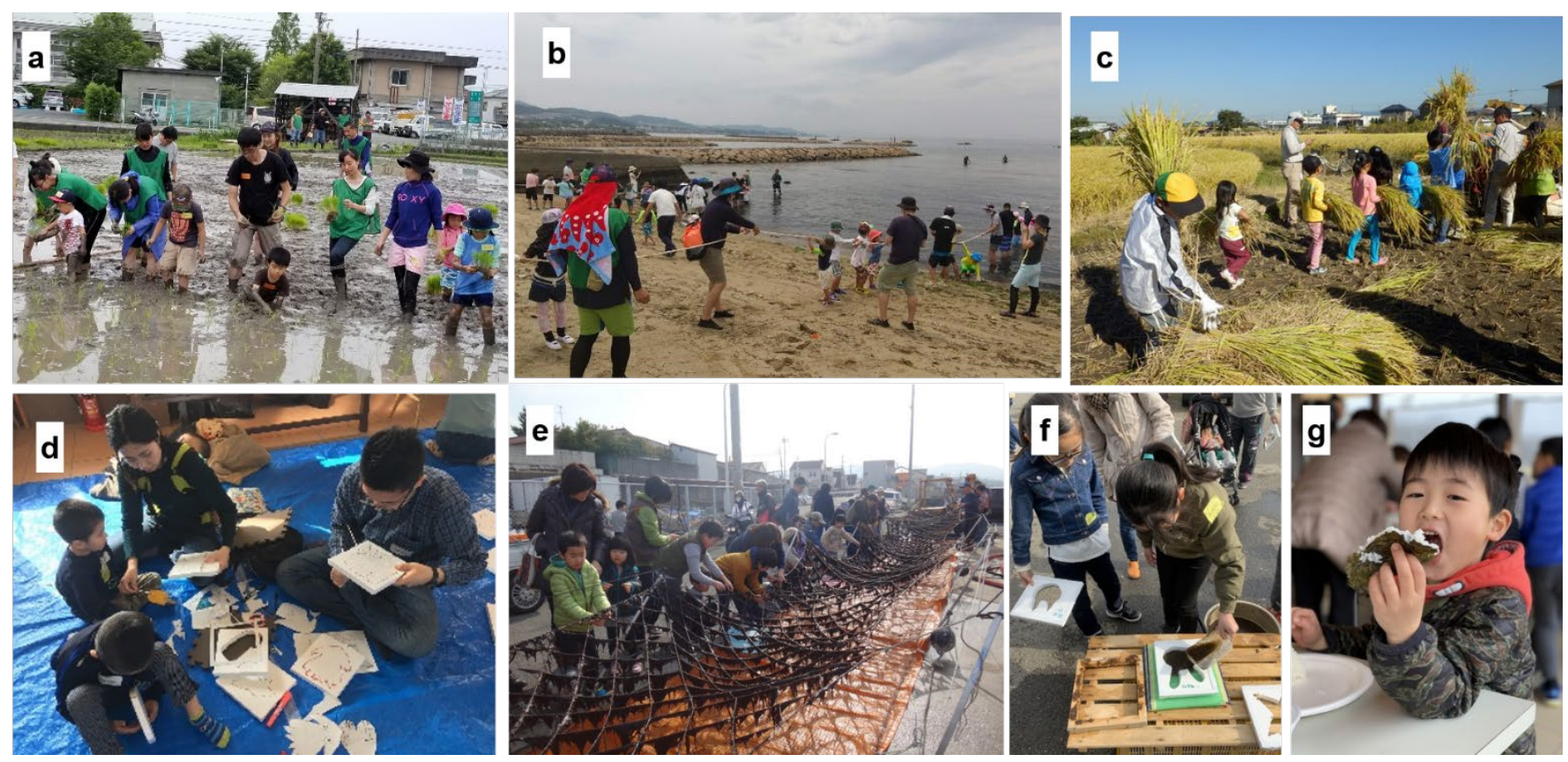

Figure 2. Hands-on environmental program in six units: planting rice in June (a), watching marine creatures and fishery experiences in August (b), rice harvesting in September (c), preparing nori harvesting in January (d), nori harvesting and making nori sheets in February (e, f), and making and eating rice balls from self-prepared rice and nori in March (g). Photographs by Katsumi Iwai and the author.

Table 2. Number of registered participants in the program

\begin{tabular}{|c|c|c|c|c|c|c|c|}
\hline & \multirow{2}{*}{ Family } & \multirow{2}{*}{ Adults } & \multicolumn{3}{|c|}{ Children } & \multirow{2}{*}{ Total } & \multirow{2}{*}{$\begin{array}{c}\text { Repeat } \\
\text { family (\%) }\end{array}$} \\
\hline & & & Junior high school & Elementary school & Kinder garden & & \\
\hline 2014 & 16 & 18 & 0 & 20 & 7 & 45 & - \\
\hline 2015 & 76 & 118 & 0 & 75 & 58 & 251 & 17 \\
\hline 2016 & 34 & 47 & 1 & 40 & 21 & 109 & 32 \\
\hline 2017 & 26 & 34 & 0 & 24 & 13 & 71 & 50 \\
\hline 2018 & 25 & 38 & 0 & 17 & 24 & 79 & 20 \\
\hline Total & 177 & 255 & 1 & 176 & 123 & 555 & - \\
\hline
\end{tabular}

However, there are only few activities related to fishery and nori harvesting because most schools have easy access to rice fields, while fish and nori fields are limited near the sea. In general, fish and nori activity is a rare opportunity even for the Japanese participants.

The program started in 2014, and the events were advertised by a local community magazine, through social networking services, such as Facebook, and emails from the event organizer to previous participants in other events. The average participant rate was 100 people per year. The number of participants in 2015 was more than the average number because the event organizer set wrong application deadline of the program. The number of registered participants and repeat (re-enrolled) families are summarized in Table 2. Repeat families are reported as the percentages of families who attended at least one earlier event among the total number of families enrolled in the year. Participants paid 3000 JPY (approximately 30 US\$) to join the program and were required to attend all events.

\section{On-Site Questionnaire Survey}

On-site survey has been applied to investigate people's perceptions (Égerházi et al., 2013; Littlejohn et al., 2016). The on-site questionnaire survey in this study, mostly assigned to adults, investigated the participants' perceptions of Osaka Bay and their attitudes toward rice, fish, and local fish consumption before and after attending the events (Supplemental material, Questionnaire). The items for the perceptions of Osaka Bay were derived from the questionnaire used of Kuroda et al. (2016) while the rest of the items were designed for this study. The on-site survey was conducted after the end of each event. Questionnaire sheet was handed out to the participants directly, however, there was no interview. In the information section, the participants were asked to provide their residence area, age, and gender. The attitude section investigated the effect of the events on the participants' frequency of rice, fish, and local fish consumption compared to before they participated the event. The participants answered "eat less" (scored 1), "no change" (scored 2), or "eat more" (scored 3) for each food item. To assess their perceptions of Osaka Bay, the participants were asked to rate the following items on a scale of 1 (low score) to 5 (high score): (1) beautiful-dirty, (2) natural-artificial, (3) familiarunfamiliar, (4) easy-difficult access, and (5) fish abundancefish scarcity. Cronbach's alpha was calculated to determine the internal reliability. The value of perceptions items and attitude items were ranged from 0.74 to 0.84 and 0.49 to 0.74 , respectively, which showed an acceptable internal reliability (Taber, 2018). The event evaluation section covered the 
Table 3. Total responses of the questionnaire each year (\% of responses each year)

\begin{tabular}{|c|c|c|c|c|c|c|c|}
\hline & & 2014 & 2015 & 2016 & 2017 & 2018 & Total \\
\hline \multirow{2}{*}{ Age } & $20 s-30 s$ & $36(38)$ & $91(30)$ & $65(28)$ & $49(41)$ & $46(40)$ & $287(33)$ \\
\hline & $40 s-50 s$ & $42(44)$ & $173(57)$ & $109(46)$ & $42(36)$ & $66(58)$ & $433(50)$ \\
\hline \multirow{2}{*}{ Gender } & Male & $35(39)$ & $123(40)$ & $74(35)$ & $42(36)$ & $26(29)$ & $300(37)$ \\
\hline & Female & $56(62)$ & $184(60)$ & $139(65)$ & $76(64)$ & $65(71)$ & $520(63)$ \\
\hline \multirow{3}{*}{ Area } & Mountain side & $27(28)$ & $73(25)$ & $31(14)$ & $32(31)$ & $19(17)$ & $182(22)$ \\
\hline & Urban area & $15(15)$ & $37(13)$ & $128(60)$ & $21(20)$ & $30(27)$ & $231(28)$ \\
\hline & South & $56(57)$ & $182(62)$ & $56(26)$ & $50(49)$ & $62(56)$ & $406(50)$ \\
\hline
\end{tabular}

participants' satisfaction of the event, and whether their participation could contribute to marine environmental conservation and improvement. In the final event, the participants answered open-ended questions about the events throughout the year.

\section{Statistical Analyses}

The statistical relationships between the factors (residence, gender, and age), and changing perceptions of Osaka Bay and food attitudes of the participants were analyzed using the Kruskal-Wallis test. A non-parametric statistical method was used because normal distributions were not confirmed. Bonferroni's multiple comparison test was also applied to identify the significant relation of the event number and changing perceptions and attitudes. Data were tested using SPSS version 23.0. In addition, a text analysis of the participants' comments from the last event of the year were conducted using the software KH Coder (Higuchi, 2016). KH coder is a free software for quantitative content analysis or text mining (Higuchi, 2020) and has been widely applied in the analysis of consumers' review (Izawa et al., 2019), public opinion surveys (Iimoto et al., 2019), and effectiveness of school lessons (Ito, 2019). It is possible to quantitatively understand the participants' feelings and learning from the events with text analysis.

\section{RESULTS}

\section{Participant Descriptions}

The total responses at each year are shown in Table 3. Half of the respondents (50\%) resided near the event site to the south, while $28 \%$ and $22 \%$ lived in urban areas (Osaka/Sakai City) and mountain side, respectively. Osaka and Sakai City are government-designated cities, which are the most populated areas in Osaka Prefecture. Most of the respondents were aged between 20 and 50 (50\% in the 40-50-year range; 33\% in the 20-30-year range). The responses of the participants under 20 were assumed to be answered by children instead of their parents, and therefore the responses under 20 were not included in the age-related analysis. In addition, the participants over 60 years old were excluded in the age-related analysis due to the small number of the responses. The proportions of the male and female respondents were $37 \%$ and $63 \%$, respectively. The main motivations for joining the program were "For kids' environmental education” (41\%), "Interest in environmental protection" (12\%), "Interest in creatures" (12\%), and "Interest in harvesting" (10\%). Only $7.0 \%$ of the participants joined for reasons related to the marine environment even though some families were repeated. Most of the participants have never visited Osaka Bay or have only visited a few times annually (Table S1 in Appendix). Resident in the south visited Osaka Bay for a walk more frequently than the other residents, suggesting the residences affect the visiting opportunities compared to age and gender. However, resident in the south is less interested in environmental activity than the other residents (Table S2 in Appendix).

\section{Changes in Perceptions and Attitude}

Event number had a statistical interaction with the change of perceptions, which is related to the residence, gender, and age (Table 4). Participants from the mountain side showed a statistical change in the beautiful, natural, and fish abundance

Table 4. Perceptions on Osaka Bay with the event number, residences, gender, and age

\begin{tabular}{|c|c|c|c|c|c|c|c|c|c|c|c|c|}
\hline & Event No. & & 1 & 2 & 3 & 4 & 5 & 6 & \multirow{2}{*}{$\begin{array}{c}\text { Reliability } \\
\begin{array}{c}\text { Cronbach's } \\
\text { alpha }\end{array}\end{array}$} & \multicolumn{2}{|c|}{$\begin{array}{c}\text { Kruskal Wallis } \\
\text { Test }\end{array}$} & \multirow{2}{*}{$\begin{array}{c}\begin{array}{c}\text { Multiple } \\
\text { comparison }\end{array} \\
\text { Event number } \\
\end{array}$} \\
\hline & Item & $\mathbf{N}$ & \multicolumn{6}{|c|}{ Mean } & & Hs & p-value & \\
\hline \multirow{5}{*}{ Mountain side } & Beautiful * & 178 & 2.4 & 2.8 & 2.6 & 3.2 & 3.0 & 2.9 & \multirow{5}{*}{0.82} & 14.1 & 0.015 & $1 \& 4$ \\
\hline & Natural * & 178 & 2.4 & 2.4 & 2.8 & 2.6 & 2.8 & 3.1 & & 13.5 & 0.019 & $1 \& 6$ \\
\hline & Familiar & 178 & 3.0 & 3.2 & 3.2 & 3.3 & 3.4 & 3.4 & & 2.92 & 0.71 & \\
\hline & Easy access & 177 & 3.1 & 3.1 & 2.8 & 3.2 & 3.4 & 3.4 & & 5.65 & 0.34 & \\
\hline & Fish abundance * & 137 & 2.9 & 2.9 & 2.8 & 3.4 & 3.4 & 3.6 & & 12.2 & 0.032 & \\
\hline \multirow{5}{*}{ Urban area } & Beautiful * & 227 & 2.3 & 2.7 & 2.5 & 3.0 & 2.8 & 3.0 & \multirow{5}{*}{0.79} & 13.5 & 0.019 & $1 \& 6$ \\
\hline & Natural & 228 & 2.4 & 2.8 & 2.2 & 2.8 & 2.7 & 2.7 & & 9.74 & 0.083 & \\
\hline & Familiar * & 228 & 2.9 & 3.4 & 3.1 & 3.6 & 3.4 & 3.2 & & 11.6 & 0.041 & \\
\hline & Easy access & 228 & 3.1 & 3.6 & 3.2 & 3.7 & 3.4 & 3.4 & & 7.29 & 0.20 & \\
\hline & Fish abundance & 208 & 2.8 & 3.0 & 2.9 & 3.4 & 3.3 & 3.3 & & 9.16 & 0.10 & \\
\hline
\end{tabular}

*p $<0.05, * * \mathrm{p}<0.01, * * * \mathrm{p}<0.001$

$\mathrm{N}$ means total responses. 
Table 4 (continued). Perceptions on Osaka Bay with the event number, residences, gender, and age

\begin{tabular}{|c|c|c|c|c|c|c|c|c|c|c|c|c|}
\hline & Event No. & & 1 & 2 & 3 & 4 & 5 & 6 & \multirow{2}{*}{$\begin{array}{c}\text { Reliability } \\
\begin{array}{c}\text { Cronbach's } \\
\text { alpha }\end{array}\end{array}$} & \multicolumn{2}{|c|}{$\begin{array}{c}\text { Kruskal Wallis } \\
\text { Test }\end{array}$} & \multirow{2}{*}{$\begin{array}{c}\begin{array}{c}\text { Multiple } \\
\text { comparison }\end{array} \\
\text { Event number }\end{array}$} \\
\hline & Item & $\mathbf{N}$ & \multicolumn{6}{|c|}{ Mean } & & Hs & p-value & \\
\hline \multirow{5}{*}{ South } & Beautiful ** & 397 & 2.6 & 2.8 & 2.8 & 3.1 & 3.2 & 2.9 & \multirow{5}{*}{0.81} & 20.0 & 0.001 & $1 \& 4,1 \& 5$ \\
\hline & Natural & 394 & 2.7 & 2.8 & 2.8 & 2.9 & 3.0 & 3.0 & & 4.35 & 0.50 & \\
\hline & Familiar * & 391 & 3.3 & 3.4 & 3.4 & 3.7 & 3.7 & 3.8 & & 11.8 & 0.037 & \\
\hline & Easy access & 396 & 3.6 & 3.7 & 3.8 & 3.8 & 3.8 & 3.9 & & 2.44 & 0.79 & \\
\hline & Fish abundance & 317 & 3.2 & 3.4 & 3.3 & 3.4 & 3.7 & 3.5 & & 6.61 & 0.25 & \\
\hline \multirow{5}{*}{ Male } & Beautiful & 293 & 2.6 & 2.8 & 2.9 & 3.0 & 3.0 & 2.9 & \multirow{5}{*}{0.74} & 9.86 & 0.079 & \\
\hline & Natural & 293 & 2.5 & 2.6 & 2.8 & 2.6 & 2.8 & 3.0 & & 7.93 & 0.16 & \\
\hline & Familiar & 292 & 3.2 & 3.3 & 3.3 & 3.2 & 3.6 & 3.6 & & 7.33 & 0.20 & \\
\hline & Easy access & 293 & 3.4 & 3.7 & 3.6 & 3.3 & 3.6 & 3.8 & & 7.80 & 0.17 & \\
\hline & Fish abundance $* *$ & 240 & 3.0 & 3.5 & 3.2 & 3.0 & 3.7 & 3.5 & & 16.4 & 0.006 & $1 \& 5$ \\
\hline \multirow{5}{*}{ Female } & Beautiful $* * *$ & 507 & 2.3 & 2.8 & 2.6 & 3.1 & 3.0 & 3.0 & \multirow{5}{*}{0.83} & 43.6 & 0.000 & $\begin{array}{c}1 \& 4,1 \& 5,1 \& 6 \\
3 \& 4\end{array}$ \\
\hline & Natural $* *$ & 505 & 2.5 & 2.6 & 2.6 & 3.0 & 2.9 & 2.9 & & 15.6 & 0.008 & \\
\hline & Familiar $* *$ & 503 & 3.1 & 3.4 & 3.3 & 3.8 & 3.7 & 3.5 & & 20.6 & 0.001 & $1 \& 4,1 \& 5$ \\
\hline & Easy access & 505 & 3.3 & 3.3 & 3.4 & 3.8 & 3.7 & 3.5 & & 9.42 & 0.093 & \\
\hline & Fish abundance $* *$ & 421 & 3.1 & 3.1 & 3.0 & 3.5 & 3.5 & 3.4 & & 15.9 & 0.007 & \\
\hline \multirow{5}{*}{$20 s-30 s$} & Beautiful $* * *$ & 281 & 2.3 & 2.9 & 2.7 & 3.0 & 2.8 & 3.1 & \multirow{5}{*}{0.84} & 24.6 & 0.000 & $1 \& 4,1 \& 6$ \\
\hline & Natural & 280 & 2.4 & 2.7 & 2.5 & 2.6 & 2.7 & 3.0 & & 8.40 & 0.136 & \\
\hline & Familiar & 279 & 3.1 & 3.5 & 3.3 & 3.5 & 3.5 & 3.3 & & 6.41 & 0.269 & \\
\hline & Easy access & 279 & 3.4 & 3.5 & 3.4 & 3.5 & 3.2 & 3.5 & & 1.48 & 0.915 & \\
\hline & Fish abundance & 232 & 2.9 & 3.4 & 3.2 & 3.2 & 3.5 & 3.4 & & 10.0 & 0.074 & \\
\hline \multirow{5}{*}{$40 s-50 s$} & Beautiful $* * *$ & 423 & 2.4 & 2.6 & 2.8 & 3.1 & 3.1 & 2.9 & \multirow{5}{*}{0.81} & 33.7 & 0.000 & $\begin{array}{c}1 \& 4,1 \& 5,1 \& 6 \\
2 \& 4\end{array}$ \\
\hline & Natural $* * * *$ & 423 & 2.3 & 2.4 & 2.7 & 3.0 & 2.9 & 2.9 & & 27.8 & 0.000 & $\begin{array}{c}1 \& 4,1 \& 5,1 \& 6 \\
2 \& 4\end{array}$ \\
\hline & Familiar $* * * *$ & 422 & 3.1 & 3.3 & 3.5 & 3.7 & 3.8 & 3.7 & & 24.6 & 0.000 & $1 \& 4,1 \& 5$ \\
\hline & Easy access $* * *$ & 423 & 3.3 & 3.5 & 3.6 & 3.8 & 3.8 & 3.7 & & 13.4 & 0.020 & $1 \& 5$ \\
\hline & Fish abundance * & 351 & 3.0 & 3.0 & 3.0 & 3.4 & 3.5 & 3.3 & & 13.6 & 0.019 & \\
\hline
\end{tabular}

*p $<0.05, * * p<0.01, * * * p<0.001$

$\mathrm{N}$ means total responses.

items ( $\mathrm{p}=0.015,0.019$, and 0.032 , respectively). On the other hand, participants from the south and urban area also showed a positive change in the beautiful $(\mathrm{p}=0.001$ and 0.019 , respectively) and familiar aspects $(\mathrm{p}=0.037$ and 0.041 , respectively). There was no impact on the perception for the residents with easy access. According to multiple comparison test, there were statistical interactions between the event numbers. Event 1 and later events (events 4, 5, and 6) statistically differed, suggesting the progression of the changes of the participants' perceptions throughout the program. It was clear that females tended to change their perceptions more significantly than males. Females showed a significant change in the beautiful, natural, familiar and fish abundance items $(\mathrm{p}=0.000,0.008,0.001$, and 0.007 , respectively) while males showed positive change only in terms of fish abundance $(p=0.006)$. Strong interactions (beautiful and familiar for females and fish abundance for males) between event 1 and later events (events 4, 5, and 6) were also found. 40 s -50 s also showed a significant change in all the items though 20s-30s showed a positive change in the beautiful only $(\mathrm{p}=0.000)$.

The event number also affected the participants' attitude toward rice and fish consumption with statistical differences based on the residences, gender, and age; however, there were no interactions between the event number and attitude toward local fish consumption (Table 5). Residents in the south and urban area showed a positive change toward rice consumption ( $p=0.026$ and 0.001 , respectively). On the other hand, the attitude toward the fish consumption of residents in the mountain side positively changed $(p=0.049)$ especially between event 3 and 6 . Females changed their attitude toward rice and fish consumption more positively than males $(\mathrm{p}=$ 0.002 for rice and 0.005 for fish). 20s-30s showed a positive change in fish consumption while $40 \mathrm{~s}-50$ s showed a positive change in rice consumption.

Rice is a standard Japanese dish as shown in the questionnaire of event 1 with over $90 \%$ of the participants responding that they eat rice almost every day (Table S3 in Appendix). Therefore, the possibility of increased frequency of eating rice is questionable. On the other hand, the participants could increase the consumption of fish, including those caught in Osaka Bay (Tables S4 and S5 in Appendix). Though the attitude toward fish and local fish did not statistically change, except the attitude of mountainside participants and 20s-30s showed a positive toward fish, the scores toward local fish tended to be higher than the rice and 
Table 5. Attitude toward rice, fish and local fish with the event number, residences, gender, and age

\begin{tabular}{|c|c|c|c|c|c|c|c|c|c|c|c|}
\hline & Event No. & & 2 & 3 & 4 & 5 & 6 & \multirow{2}{*}{$\begin{array}{c}\text { Reliability } \\
\begin{array}{c}\text { Cronbach's } \\
\text { alpha }\end{array} \\
\end{array}$} & \multicolumn{2}{|c|}{$\begin{array}{c}\text { Kruskal Wallis } \\
\text { Test } \\
\end{array}$} & \multirow{2}{*}{$\begin{array}{c}\begin{array}{c}\text { Multiple } \\
\text { comparison }\end{array} \\
\text { Event number }\end{array}$} \\
\hline & Item & $\mathbf{N}$ & & & Mean & & & & Hs & p-value & \\
\hline \multirow{3}{*}{$\begin{array}{l}\text { Mountain } \\
\text { side }\end{array}$} & Rice & 125 & 2.3 & 2.2 & 2.4 & 2.4 & 2.5 & \multirow{3}{*}{0.74} & 4.97 & 0.29 & \\
\hline & Fish * & 125 & 2.3 & 2.1 & 2.2 & 2.3 & 2.5 & & 9.53 & 0.049 & $3 \& 6$ \\
\hline & Local fish & 125 & 2.4 & 2.4 & 2.4 & 2.3 & 2.6 & & 3.21 & 0.52 & \\
\hline \multirow{3}{*}{ Urban area } & Rice $* *$ & 167 & 2.2 & 2.3 & 2.4 & 2.4 & 2.7 & \multirow{3}{*}{0.59} & 18.5 & 0.001 & $2 \& 6,3 \& 6$ \\
\hline & Fish & 167 & 2.3 & 2.3 & 2.3 & 2.5 & 2.5 & & 7.21 & 0.13 & \\
\hline & Local fish & 168 & 2.4 & 2.4 & 2.4 & 2.5 & 2.6 & & 3.71 & 0.45 & \\
\hline \multirow{3}{*}{ South } & Rice * & 305 & 2.4 & 2.3 & 2.5 & 2.3 & 2.5 & \multirow{3}{*}{0.57} & 11.0 & 0.026 & $3 \& 6$ \\
\hline & Fish & 304 & 2.3 & 2.3 & 2.4 & 2.5 & 2.4 & & 4.78 & 0.31 & \\
\hline & Local fish & 303 & 2.5 & 2.5 & 2.6 & 2.6 & 2.6 & & 3.83 & 0.43 & \\
\hline \multirow{3}{*}{ Male } & Rice & 205 & 2.2 & 2.3 & 2.3 & 2.3 & 2.4 & \multirow{3}{*}{0.49} & 4.91 & 0.30 & \\
\hline & Fish & 206 & 2.2 & 2.2 & 2.3 & 2.4 & 2.3 & & 5.50 & 0.24 & \\
\hline & Local fish & 205 & 2.3 & 2.3 & 2.4 & 2.4 & 2.4 & & 1.67 & 0.80 & \\
\hline \multirow{3}{*}{ Female } & Rice $* * *$ & 388 & 2.4 & 2.3 & 2.5 & 2.4 & 2.6 & \multirow{3}{*}{0.66} & 16.5 & 0.002 & $3 \& 6$ \\
\hline & Fish ** & 387 & 2.3 & 2.3 & 2.4 & 2.5 & 2.5 & & 15.0 & 0.005 & $3 \& 6$ \\
\hline & Local fish & 388 & 2.5 & 2.5 & 2.5 & 2.6 & 2.6 & & 4.82 & 0.31 & \\
\hline \multirow{3}{*}{$20 s-30 s$} & Rice & 195 & 2.5 & 2.3 & 2.5 & 2.5 & 2.6 & \multirow{3}{*}{0.67} & 7.19 & 0.126 & \\
\hline & Fish * & 196 & 2.5 & 2.3 & 2.3 & 2.6 & 2.6 & & 12.9 & 0.012 & \\
\hline & Local fish & 195 & 2.6 & 2.4 & 2.5 & 2.6 & 2.6 & & 4.38 & 0.357 & \\
\hline \multirow{3}{*}{$40 s-50 s$} & Rice $* *$ & 327 & 2.3 & 2.3 & 2.4 & 2.4 & 2.6 & \multirow{3}{*}{0.61} & 16.2 & 0.003 & $2 \& 6,3 \& 6$ \\
\hline & Fish & 328 & 2.4 & 2.3 & 2.3 & 2.5 & 2.5 & & 6.74 & 0.150 & \\
\hline & Local fish & 328 & 2.5 & 2.5 & 2.5 & 2.6 & 2.6 & & 4.88 & 0.300 & \\
\hline
\end{tabular}

*p $<0.05, * * p<0.01, * * * p<0.001$

$\mathrm{N}$ means total responses.

fish items. This implies that the event programs contributed in promoting the consumption of local fish to the participants. When averaged over all the events, the score of the attitude toward local fish in the south was highest among all the residents (2.6 for south, 2.5 for urban area, and 2.4 for mountain side). The attitude toward fish and local fish consumption in the south and mountain side was almost similar at event 1 (Table S5 in Appendix), indicating that living near Osaka Bay encouraged the purchase of local fish, which is derived from the location advantage suggested by Kuroda and Otsuka (2018).

\section{Event Evaluation}

When asked regarding their satisfaction and sense of contribution to marine environmental protection, $94 \%$ of the participants were satisfied with the events and $88 \%$ agreed that the events contributed to the conservation of the marine environment. The proportions of the repeat participants in Table 2 reflect the high satisfaction with the program. The participants' evaluation on the events was demonstrated through a co-occurrence network of their comments (Figure 3). In this figure, the size of the circles represents the frequency of the words used in the participants' comments. Groups with different color, as represented as Subgraph in Figure 3, denote strong link with each other. Common words included "living experience," "appreciation," "participation," and "children." Participants rated the living experiences as highly valuable and enjoyable, and expressed their appreciation. The experiences in the events linked Osaka Bay, sea, and fish to the participants' lives, and improved their familiarity with these resources. Moreover, "cook" and "harvest" were connected to "myself" and "hands," respectively, and each group included "in real," and "realistic," respectively, suggesting that the participants gained "living experiences" through the events.

\section{DISCUSSIONS}

The main findings from the questionnaire survey are as follows. First, continuous participation improved the participants' perceptions of Osaka Bay and can affect their rice and fish consumption at home. Strong positive relations between event 1 and later events can be driven by continuous participation. Second, living and realistic experiences, such as rice planting and nori harvesting increased participants' familiarity with Osaka Bay.

Based on the questionnaire survey which suggested that most of the participants did not frequently visit Osaka Bay (Table S1 in Appendix), this program offered participants the opportunity to visit coastal area of Osaka Bay especially for the participants from the mountain side and urban areas. However, it was not determined whether continuous visit to the site or environmental topic of the program change the participants' perceptions. The effects varied with their area of residence. The participants from the mountain side showed a positive change in the "natural" characteristics and "fish abundance," however, they did not show a positive change in the "familiar," which differed for the participants from the south and urban areas. The connection between the mountain 


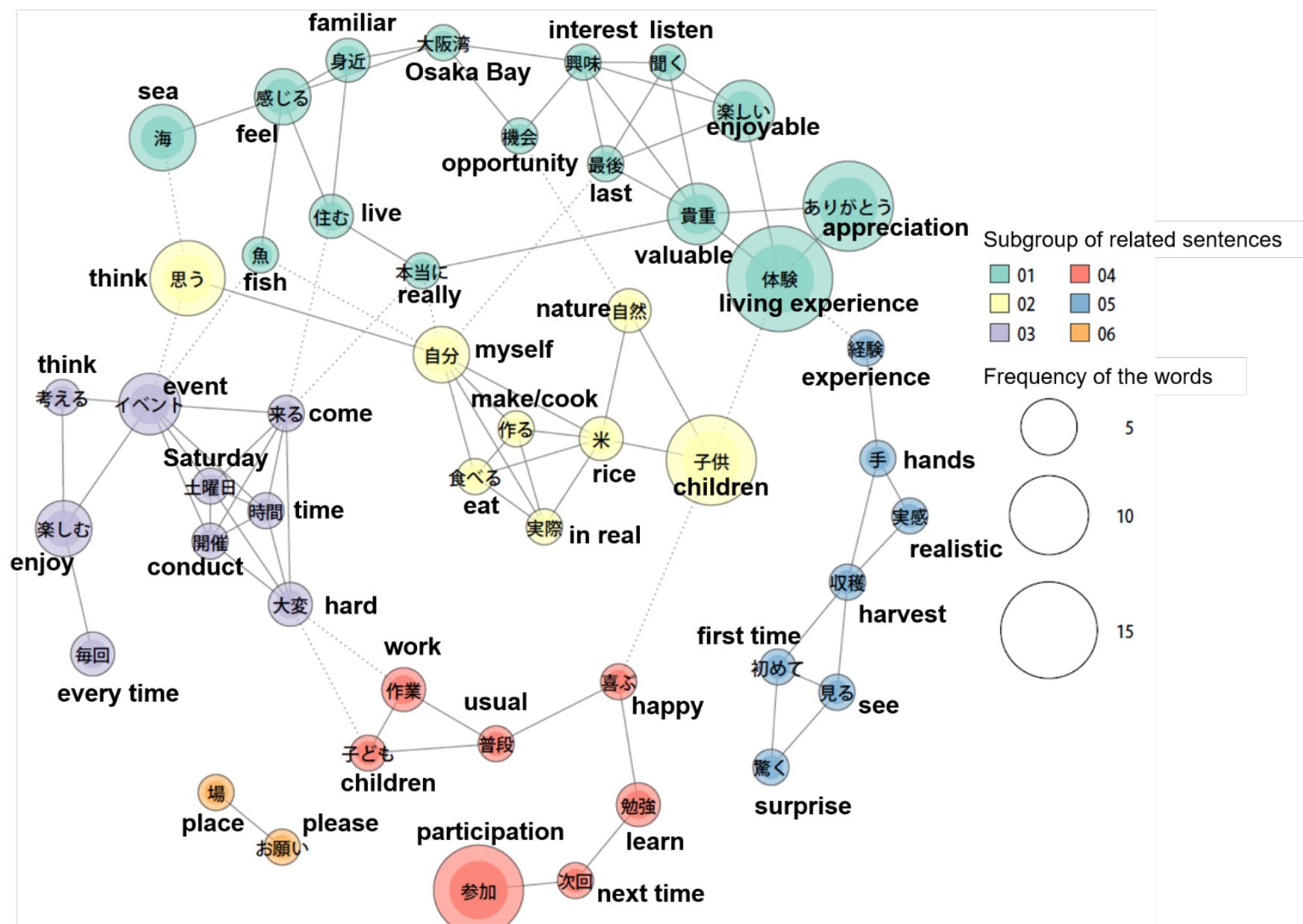

Figure 3. Co-occurrence network of words used in the participants' evaluations (after the last event). The size of the circles represents the frequency of the words used in participants' comments. Groups with different color denote strong link with each other

side and Osaka Bay is less straightforward, implying that location affects familiarity with Osaka Bay.

The participants aged 40s-50s improved their perceptions toward Osaka Bay much more positively than the participants aged $20 \mathrm{~s}-30 \mathrm{~s}$, probably because there is a positive relation between age and ecological behavior (Otto and Kaiser, 2014). Participants' exposure to new information or experiences related to local sea or local food was effective in the participants aged $40 \mathrm{~s}-50$ s even though the program consisted of short-period events. Other socio-economic variables such as education and income should be included in the questionnaire for in-depth analysis. The program exerted more positive influences on females than on males, probably because women serve as the main cooks in Japanese homes. Women spend more time cooking and completing other household tasks than men in Japan (2.24 h daily for females versus $0.19 \mathrm{~h}$ daily for males) (Statistics Bureau, 2016). Therefore, they usually decide the content of the family's meals and are more amenable to changing their food attitudes. Females might also be more willing to engage in proenvironmental consumer behavior than males, which might slightly change their attitudes as suggested by Tarrant and Lyons (2012) and Wester and Eklund (2011).

The program provided the participants with "living experiences," which connected to "valuable," “opportunity,"
"Osaka Bay," and "familiar" as shown in Figure 3. The experiential process of planting and harvesting rice and nori to eating rice balls made from these products linked the people to the coastal environment though most of the original reasons they participated in the program were environmental education for children. This conclusion leads to promoting ocean citizenship, which describes a relationship between our everyday lives and the health of the coastal and marine environment (Fletcher and Potts, 2007).

Unfortunately, whether participants maintained their positive perception of Osaka Bay and attitude toward eating rice and fish could not be evaluated after the program was completed. Furthermore, this study did not analyze the relation with the personal characteristics except residence, gender, and age. According to Dunkley (2016), individual personal life, prior experiences and wider sociocultural contexts have a strong influence on the perceptions, motivations, and resulting actions. From an optimistic perspective, this attitude continues once an environmentally friendly behavior is established (Wester and Eklund, 2011). However, further research should investigate whether such programs exert a lasting effect. The topic of the program varied with both country and community, thereby making it is still difficult in generalizing the findings in this study. For the next step, the contents of the present program need to be expanded 
to develop coastal literacy, and the effectiveness of informal and adult learning education can be explored in depth.

\section{CONCLUSIONS}

Hands-on environmental events held in Hannan City (southern Osaka, Japan) showed that continuous participation improved adults' perceptions toward Osaka Bay, and changed their attitudes to local foods (rice and fish), by providing living experiences. The developed program explored the potential to link people with the ecosystem service of coastal area. A questionnaire survey found that the area of residence, gender, and age could be factors in determining the positive perceptions of Osaka Bay, which should be considered in event design to improve effectiveness of the events. A follow-up of the participants' behavior after completing the events would indicate the socio-economic factors that would maintain positive perceptions and attitudes toward Osaka Bay and its local food resources. Although holding similar events in other areas is both financially and socially difficult (requiring collaboration with local community), these events can potentially assist marine related education, which is not easily included in school curriculum. This attempt contributes to the literature on the methodology of environmental education outside school and is a powerful tool for environmental education.

Funding: This work was partially supported by JST RISTEX Grant Number JPMJRX16E7, Japan.

Declaration of interest: There are no conflicts of interest to declare.

Acknowledgements: The author thanks Mr. Katsumi Iwai, Ms. Miyako Kawahara, and all the participants for cooperation of the on-site questionnaire survey, Dr. TuAnh Nguyen for the useful advice on statistical analysis, and Mr. Kohei Ichioka, Ms. Mayu Okita, and Ms. Mika Ode for supporting the questionnaire survey.

Ethics approval and consent to participate: Not applicable.

Availability of data and materials: All data generated or analyzed during this study are available for sharing when appropriate request is directed to corresponding author.

\section{REFERENCES}

Dunkley, R. (2016). Learning at eco-attractions: Exploring the bifurcation of nature and culture through experiential environmental education. Journal of Environmental Education, 47(3), 213-221. https://doi.org/10.1080/ 00958964.2016.1164113

Égerházi, L. A., Kovács, A. and Unger, J. (2013). Application of microclimate modelling and onsite survey in planning practice related to an urban micro-environment. Advances in Meteorology, 2013, Article ID 251586. https://doi.org/10.1155/2013/251586

Fletcher, S. and Potts, J. (2007). Ocean Citizenship: An Emergent Geographical Concept. Coastal Management, 35(4), 511-524. https://doi.org/10.1080/08920750701525 818
Forrester, T. D., Baker, M., Costello, R., Kays, R., Parsons, A. W. and McShea, W. J. (2017). Creating advocates for mammal conservation through citizen science. Biological Conservation, 208, 98-105. https://doi.org/10.1016/ j.biocon.2016.06.025

Hein, M. Y., Birtles, A., Willis, B. L., Gardiner, N., Beeden, R. and Marshall, N. A. (2019). Coral restoration: Socioecological perspectives of benefits and limitations. Biological Conservation, 229, 14-25. https://doi.org/ 10.1016/j.biocon.2018.11.014

Higuchi, K. (2016). A Two-Step Approach to Quantitative Content Analysis: KH Coder Tutorial using Anne of Green Gables (Part 1). Ritsumeikan Social Sciences Review, 52, 7791.

Higuchi, K. (2020). Tutorial of KH coder. Available at: https://khcoder.net/en/ (Accessed: 6 March 2020).

Hynes S., Norton, D. and Corless, R. (2014). Investigating societal attitudes towards the marine environment of Ireland. Marine Policy, 47, 57-65. https://doi.org/10.1016/ j.marpol.2014.02.002

Iimoto, T., Takashima, R., Kimura, H., Kawakami, K., Endo, H., Yasuda, H., Nagata, N., Sakai, N., Kawasaki, Y. and Funakoshi, M. (2019). Results and Discussion on Japanese Public Opinion Surveys (2006-17) About Nuclear and Radiation Applications. Radiation Protection Dosimetry, 184(3-4), 523-526. https://doi.org/10.1093/rpd/ncz127

Ito, Y. (2019). The Effectiveness of a CLIL Basketball Lesson: A Case Study of Japanese Junior High School CLIL. English Language Teaching, 12(11). 42-54. https://doi.org/10.5539/ elt.v12n11p42

Izawa, M., Namatame, T. and Otake, K. (2019). Analysis of Characteristics of Golf Course Using User Review at Golf Portal Site. In G. Meiselwitz (Ed.), Social Computing and Social Media. Communication and Social Communities (pp. 392-402). Springer. https://doi.org/10.1007/978-3-03021905-5 30

Kuroda, K. and Otsuka, K. (2018). Why people do not care about local fish?: Proceedings of Techno-Oceans/OCEANS 2018 MTS/IEEE Conference, Kobe, IEEE Catalog Number CFP18OCF-POD, pp. 2263-2267. https://doi.org/10.1109/ OCEANSKOBE.2018.8559123

Kuroda, K., Otsuka, K. and Shimomura, Y. (2016). Environmental awareness about coastal area and behaviors of regional fish-eating: Proceedings of OCEANS 2016 MTS/IEEE Conference, Shanghai, IEEE Catalog Number CFP16OCFPOD, pp. 1093-1097. https://doi.org/10.1109/OCEANSAP. 2016.7485543

Leisher, C., Mangubhai, S., Hess, S., Widodo, H., Soekirman, T., Tjoe, S., Wawiyai, S., Larsen, S. N., Rumetna, L., Halim, A. and Sanjayan, M. (2012). Measuring the benefits and costs of community education and outreach in marine protected areas. Marine Policy, 36(5), 1005-1011. https://doi.org/ 10.1016/j.marpol.2012.02.022 
Littlejohn, K., Needham, M. D., Szuster, B. W. and Jordan, E. J. (2016). Pre-trip expectations and post-trip satisfaction with marine tour interpretation in Hawaii: Applying the norm activation model. Journal of Environmental Education, 47(3), 202-212. https://doi.org/10.1080/00958964.2016. 1162132

Mace, G. M. (2014). Whose conservation? Changes in the perception and goals of nature conservation require a solid scientific basis. Science, 345(6204), 1558-1560. https://doi.org/10.1126/science.1254704

MAFF (Ministry of Agriculture, Forestry and Fisheries). (2017). Available at: https://www.maff.go.jp/ (Accessed: 22 January 2021).

McKinley, E. and Fletcher S. (2010). Individual responsibility for the oceans? An evaluation of marine citizenship by UK marine practitioners. Ocean and Coastal Management, 53(7), 379-384. https://doi.org/10.1016/j.ocecoaman.2010. 04.012

Monterey Bay Aquarium. (2020). Seafood Watch program, Available at: https://www.seafoodwatch.org/ (Accessed: 17 November 2020).

Osaka Prefecture (2014). (in Japanese). Report for questionnaire survey about Plan of Rich Inner Sea in Osaka. Available at: www.pref.osaka.lg.jp/attach/4982/00145820/HPanaumidu kuri.docx (Accessed 16 July 2019).

Otto, S. and Kaiser, F. G. (2014). Ecological behavior across the lifespan: Why environmentalism increases as people grow older. Journal of Environmental Psychology, 40, 331-338. https://doi.org/10.1016/j.jenvp.2014.08.004

Otto, S. and Pensini, P. (2017). Nature-based environmental education of children: Environmental knowledge and connectedness to nature, together, are related to ecological behaviour. Global Environmental Change, 47, 88-94. https://doi.org/10.1016/j.gloenvcha.2017.09.009

Pearson, N., Biddle, S. and Gorely, T. (2009). Family correlates of breakfast consumption among children and adolescents. A systematic review. Appetite, 52(1), 1-7. https://doi.org/ 10.1016/j.appet.2008.08.006

Pendleton, L., Martin, N. and Webster, D. G. (2001). Public Perceptions of Environmental Quality: A Survey Study of Beach Use and Perceptions in Los Angeles County. Marine Pollution Bulletin, 42(11), 1155-1160. https://doi.org/ 10.1016/S0025-326X(01)00131-X

Sattler, S. and Bogner, F. X. (2017). Short- and long-term outreach at the zoo: cognitive learning about marine ecological and conservational issues. Environmental Education Research, 23(2), 252-268. https://doi.org/10.1080 $/ 13504622.2016 .1144173$
Sharp, R. L., Cleckner, L. B. and DePillo, S. (2017). The impact of on-site educational outreach on recreational users' perceptions of aquatic invasive species and their management. Environmental Education Research, 23(8), 1200-1210.

https://doi.org/10.1080/13504622.2016.1174983

Statistics Bureau, Ministry of Internal Affairs and Communication. (2016). (in Japanese). Fundamental investigation about social life. Available at: https://www.stat.go.jp/data/shakai/2016/pdf/index.htm (Accessed 17 July 2019).

Sutherland, D. S. and Ham, S. H. (1992). Child-to-parent transfer of environmental ideology in Costa Rican families: An ethnographic case study. Journal of Environmental Education, 23(3), 9-16. https://doi.org/10.1080/00958964. 1992.9942797

Taber, K. (2018). The Use of Cronbach's Alpha When Developing and Reporting Research Instruments in Science Education. Research in Science Education, 48(1), 1273-1296. https://doi.org/10.1007/s11165-016-9602-2

Tarrant, M. and Lyons, K. (2012). The effect of short-term educational travel programs on environmental citizenship. Environmental Education Research, 18(3), 403-416. https://doi.org/10.1080/13504622.2011.625113

Tian, Y., Wu, H., Zhang, G., Wang, L., Zheng, D. and Li, S. (2020). Perceptions of ecosystem services, disservices and willingness-to-pay for urban green space conservation. Journal of Environmental Management, 260, 110140. https://doi.org/10.1016/j.jenvman.2020.110140

Torres, H. R., Reynolds, C. J., Lewis, A., Muller-Karger, F., Alsharif, K. and Mastenbrook, K. (2019). Examining youth perceptions and social contexts of litter to improve marine debris environmental education. Environmental Education Research, 25(9), 1400-1415. https://doi.org/10.1080/ 13504622.2019.1633274

UNESCO. (2014). Shaping the Future We Want, UN Decade of Education for Sustainable Development (2005-2014) Final Report. Available at: https://unesdoc.unesco.org/ark:/ 48223/pf0000230171 (Accessed: 8 November 2019).

Wester, M. and Eklund, B. (2011). "My husband usually makes those decisions": Gender, behavior, and attitudes toward the marine environment. Environmental Management, 48(1), 70-80. https://doi.org/10.1007/s00267-011-9676-6 


\section{APPENDIX}

\section{Questionnaire}

About the participants

1) In what prefecture and city are you resident of?

$\bigcirc$ Prefecture ( ) $\bigcirc$ City ( )

2) What is your gender?

$\bigcirc$ Male $\bigcirc$ Female

3) What is your age?

$\bigcirc$ 10s $\bigcirc$ 20s $\bigcirc$ 30s $\bigcirc$ 40s $\bigcirc$ 50s $\bigcirc$ 60s $\bigcirc$ more than 70s

\section{About eating rice, fish, and local fish and visiting Osaka Bay (Ask this only for event1)}

4) How many times do you eat rice at home?

$\bigcirc$ Almost every day $\bigcirc$ 3-4 times a week $\bigcirc$ 1-2 times a week $\bigcirc$ Never

5) How many times do you eat fish at home?

$\bigcirc$ Almost every day $\bigcirc$ 3-4 times a week $\bigcirc$ 1-2 times a week $\bigcirc$ Never

6) Do you eat fish caught in Osaka Bay at home?

$\bigcirc$ Often $\bigcirc$ Sometimes $\bigcirc$ Never/ Does not remember

7) How many times do you visit Osaka Bay?

$\bigcirc$ Almost every day $\bigcirc 1-2$ times a month $\bigcirc 1-2$ times a year $\bigcirc$ Never

About attitude toward eating rice, fish, and local fish after the event (Ask this except for event1)

8) Do you eat rice more frequently than before participating in the last event?

$\bigcirc$ Eat less $\bigcirc$ No change $\bigcirc$ Eat more

9) Do you eat fish more frequently than before participating in the last event?

$\bigcirc$ Eat less $\bigcirc$ No change $\bigcirc$ Eat more

10) Do you eat local fish more frequently than before after participating in the last event?

$\bigcirc$ Eat less $\bigcirc$ No change $\bigcirc$ Eat more

\section{About perceptions on Osaka Bay}

11) Mark only one number that is the closest to your perceptions of Osaka Bay.

$\begin{array}{lll}\text { Dirty } & 1-2-3-4-5 & \text { Beautiful } \\ \text { Artificial } & 1-2-3-4-5 & \text { Natural } \\ \text { Unfamiliar } & 1-2-3-4-5 & \text { Familiar } \\ \text { Difficult access } & 1-2-3-4-5 & \text { Easy access } \\ \text { Fish scarcity } & 1-2-3-4-5 & \text { Fish abundance }\end{array}$

\section{About events}

12) What motivated you to enroll in the event? Multiple answers allowed. (Ask this only for event1)

$\bigcirc$ Interest in environmental conservation

For kids' environmental education

$\bigcirc$ Interest in marine environment

Interest in rice field

$\bigcirc$ Interest in animals

$\bigcirc$ Interest in consuming rice ball

It was valuable experiences last year (Repeat participants).

Others ( 
13) Are you satisfied with the events?

$\bigcirc$ Satisfied $\bigcirc$ Slightly satisfied $\bigcirc$ Neutral $\bigcirc$ Slightly dissatisfied $\bigcirc$ Dissatisfied

14) Do you think that these events will contribute in conserving and improving marine environment?

$\bigcirc$ Agree $\bigcirc$ Slightly agree $\bigcirc$ Neutral $\bigcirc$ Slightly disagree $\bigcirc$ Disagree

15) Make brief comments about the six events (Ask this only for event 6).
(
) 
Table S1. Frequency of visiting Osaka Bay (\% of responses)

\begin{tabular}{|c|c|c|c|c|c|c|}
\hline & & Every day & 1-2 times a week & $\begin{array}{c}\text { 1-2 times a } \\
\text { month }\end{array}$ & 1-2 times a year & Never \\
\hline \multirow{3}{*}{ Residence } & Mountain side & $0(0)$ & $1(2)$ & $6(15)$ & $18(44)$ & $16(39)$ \\
\hline & Urban area & $0(0)$ & $0(0)$ & $7(13)$ & $30(55)$ & $18(33)$ \\
\hline & South & $2(2)$ & $4(4)$ & $34(37)$ & $39(43)$ & $12(13)$ \\
\hline \multirow{2}{*}{ Gender } & Male & $1(1)$ & $2(3)$ & $20(27)$ & $30(41)$ & $20(27)$ \\
\hline & Female & $1(1)$ & $2(2)$ & $23(21)$ & $58(52)$ & $28(25)$ \\
\hline \multirow{2}{*}{ Age } & $20 s-30 s$ & $0(0)$ & $2(3)$ & $21(29)$ & $31(43)$ & $19(26)$ \\
\hline & $40 s-50 s$ & $1(1)$ & $2(2)$ & $21(23)$ & $50(54)$ & $18(20)$ \\
\hline
\end{tabular}

Table S2. Purpose of visiting Osaka Bay (\% of responses)

\begin{tabular}{|c|c|c|c|c|c|c|c|c|}
\hline & & Work & For a walk & $\begin{array}{l}\text { Seeing } \\
\text { sunset }\end{array}$ & Fishing & Swimming & $\begin{array}{c}\text { Other } \\
\text { recreation }\end{array}$ & $\begin{array}{c}\text { Environmental } \\
\text { activity }\end{array}$ \\
\hline \multirow{3}{*}{ Residence } & Mountain side & $1(3)$ & $5(14)$ & $1(3)$ & $5(14)$ & $8(23)$ & $8(23)$ & $7(20)$ \\
\hline & Urban area & $3(6)$ & $6(13)$ & $1(2)$ & $10(21)$ & $6(13)$ & $16(34)$ & $5(11)$ \\
\hline & South & $4(3)$ & $39(32)$ & $10(8)$ & $16(13)$ & $19(15)$ & $33(27)$ & $2(2)$ \\
\hline \multirow{2}{*}{ Gender } & Male & $3(4)$ & $15(19)$ & $6(8)$ & $16(21)$ & $13(17)$ & $20(26)$ & $5(6)$ \\
\hline & Female & $3(3)$ & $31(26)$ & $6(5)$ & $14(12)$ & $23(19)$ & $34(29)$ & $8(7)$ \\
\hline \multirow{2}{*}{ Age } & $20 s-30 s$ & $3(4)$ & $19(23)$ & $7(8)$ & $13(16)$ & $13(16)$ & $22(26)$ & $7(8)$ \\
\hline & $40 s-50 s$ & $5(5)$ & $20(20)$ & $5(5)$ & $13(13)$ & $18(18)$ & $34(34)$ & $5(5)$ \\
\hline
\end{tabular}

Table S3. Frequency of eating rice at home (\% of responses)

\begin{tabular}{|c|c|c|c|c|c|}
\hline & & Every day & 3-4 times a week & 1-2 times a week & Never \\
\hline \multirow{3}{*}{ Residence } & Mountain side & $29(94)$ & $1(3)$ & $0(0)$ & $1(3)$ \\
\hline & Urban area & $47(94)$ & $1(2)$ & $1(2)$ & $1(2)$ \\
\hline & South & $68(94)$ & $3(4)$ & $1(1)$ & $0(0)$ \\
\hline \multirow{2}{*}{ Gender } & Male & $53(88)$ & $4(7)$ & $3(5)$ & $0(0)$ \\
\hline & Female & $87(98)$ & $1(1)$ & $0(0)$ & $1(1)$ \\
\hline \multirow{2}{*}{ Age } & $20 s-30 s$ & $55(95)$ & $2(3)$ & $1(2)$ & $0(0)$ \\
\hline & $40 s-50 s$ & $72(91)$ & $3(4)$ & $2(3)$ & $2(3)$ \\
\hline
\end{tabular}

Table S4. Frequency of eating fish at home (\% of responses)

\begin{tabular}{|c|c|c|c|c|c|}
\hline & & Every day & 3-4 times a week & 1-2 times a week & Never \\
\hline \multirow{3}{*}{ Residence } & Mountain side & $2(7)$ & $9(29)$ & $18(58)$ & $2(7)$ \\
\hline & Urban area & $3(6)$ & $17(33)$ & $28(55)$ & $3(6)$ \\
\hline & South & $1(1)$ & $21(29)$ & $51(70)$ & $0(0)$ \\
\hline \multirow{2}{*}{ Gender } & Male & $1(2)$ & $20(33)$ & $38(62)$ & $2(3)$ \\
\hline & Female & $3(3)$ & $26(30)$ & $57(64)$ & $3(3)$ \\
\hline \multirow{2}{*}{ Age } & $20 s-30 s$ & $2(3)$ & $10(17)$ & $44(76)$ & $2(3)$ \\
\hline & $40 s-50 s$ & $2(3)$ & $26(33)$ & $49(61)$ & $3(4)$ \\
\hline
\end{tabular}

Table S5. Frequency of eating fish caught in Osaka Bay at home (\% of responses)

\begin{tabular}{|c|c|c|c|c|}
\hline & & Often & Sometimes & $\begin{array}{c}\text { Never/ } \\
\text { Does not remember }\end{array}$ \\
\hline \multirow{3}{*}{ Residence } & Mountain side & $2(7)$ & $19(63)$ & $9(30)$ \\
\hline & Urban area & $3(7)$ & $7(17)$ & $32(76)$ \\
\hline & South & $11(15)$ & $41(57)$ & $20(28)$ \\
\hline \multirow{2}{*}{ Gender } & Male & $3(5)$ & $30(54)$ & $23(41)$ \\
\hline & Female & $12(15)$ & $35(42)$ & $36(43)$ \\
\hline \multirow{2}{*}{ Age } & $20 s-30 s$ & $9(17)$ & $25(47)$ & $19(36)$ \\
\hline & $40 s-50 s$ & $5(7)$ & $38(51)$ & $31(42)$ \\
\hline
\end{tabular}

